\title{
薬事法規教育の授業用教材設計に関する研究
}

\author{
山本大介, ${ }^{*}$ 伊藤 智 夫, 鈴木順子
}

\section{Design of Teaching Materials for Pharmaceutical Law Education}

\author{
Daisuke Yamamoto, ${ }^{*}$ Tomoo Itoh, and Junko Suzuki \\ School of Pharmacy, Kitasato University; 5-9-1 Shirokane, Minato-ku, Tokyo 108-8641, Japan.
}

(Received August 29, 2019; Accepted August 4, 2020)

\begin{abstract}
A questionnaire survey was conducted with pharmacy students to obtain useful information for preparing teaching materials in the field of pharmaceutical laws. We conducted a customer satisfaction (CS) analysis by asking pharmacy students to evaluate whether the teaching materials used in the Pharmaceutical Laws class at Kitasato University were effective in promoting learning and understanding. In addition, we asked them about their impressions of attending the Pharmaceutical Laws class and analyzed their freely described answers. The CS analysis suggested teaching materials that included case studies of pharmaceutical law judgments and violations may have been useful for learning this subject. Furthermore, the text analysis showed many of the participants believed the contents of the teaching materials were difficult. Therefore, it is necessary to redesign the contents so that learning can progress step by step from the basic items. In addition, since some students recognized that the subject could be memorized, it is possible they can convey only what they remember and not what they had learned or what knowledge they could use in other contexts and situations. Therefore, it is necessary to clearly present the learning objectives for each item in lesson's teaching materials.
\end{abstract}

Key words_ - pharmaceutical law; pharmaceutical education; teaching material

\section{緒言}

薬事に係わる法規範（以下，「薬事法規」と記載 する）は，薬学関係者の業務に直結する一生涯の行 動規範である.そのため 6 年制薬学教育を対象とし た薬学教育モデル・コアカリキュラムや， 4 年制薬 学教育課程編成上の参照基準には, 薬事法規分野の 基本的な知識の修得が学習目標に掲げられてい る. ${ }^{1,2)}$ これらのガイドラインの制定にあたつては, 薬学教育で実践すべき薬事法規分野の教育内容につ いて議論が重ねられ, 併せて, 薬学教育モデル・コ アカリキュラムの「B 薬学と社会」などの各大学 における実施状況についても調査が行われてき

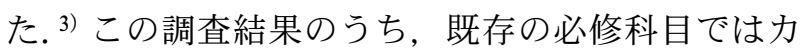
バーされていない, 又は授業での実施が難しいと回 答された割合が多かつた一部の領域については，別 途，教材や教育方法のあり方について，担当教員間 の情報共有が行われている. ${ }^{3,4)}$ しかし，「B 薬学と

北里大学薬学部

*e-mail: yamamotodai@ pharm.kitasato-u.ac.jp
社会」の中核を担っている薬事法規分野において, 実際の授業用教材について, 学習者から直接フィー ドバックを受けた報告はこれまでにない。そこで, 本研究では, 薬事法規分野の授業用教材の設計に役 立つ知見を得るために, 薬学生を対象としたアン ケート調查を実施したので報告する.

$$
\text { 方法 }
$$

1. 授業の概要 北里大学薬学部の 4 年次必修 科目「薬事関係法規」は, 90 分 $\times 10$ コマの大人数 講義の授業形式であり, 担当教員は 1 名 (山本大介) である、本科目は, 医薬品, 医療機器等の品質, 有 効性及び安全性の確保等に関する法律（医薬品医療 機器等法), 安全な血液製剤の安定供給の確保等に 関する法律，麻薬及び向精神薬取締法，覚せい剂取 締法，あへん法，大麻取締法，毒物及び劇物取締法 及びこれらの関係法令並びに関係通知などを主な授 業範囲としている，成績評価の方法は，小テストの 提出確認を $20 \%$ （1 回 2\%の全 10 回），期末試験を $80 \%$ とした。本授業は, 2018 年 4 月 10 日から 2018 年 6 月 19 日までの毎週火曜日 2 限目に実施した. 


\section{2. 授業用教材の概要 本科目で使用した教材}

は，「講義のレジュメ」及びその中にある「法情報 の調べ方」，「法制定に係る歴史的な背景」及び「薬 事分野の裁判例や違反事例」並びに「小テスト」及 び「Q\&A 集」の 6 つであり，すべて $\mathrm{A} 4$ サイズで 印刷した紙媒体の資料とした。これらの資料のう ち，「講義のレジュメ」と「小テスト」は，原則と して毎週の授業開始時に配布し，「Q\&A 集」は, 学生から質問を受けた日以降の，翌週の授業開始時 に配布した。それぞれの教材の特徵は以下の通りで ある。

「講義のレジュメ」には，法律の条文や制度の概 要とそれらの解説が記載されている．本教材は，本 科目の授業範囲を網羅した基本書として使用するた めに作成した。さらに，「講義のレジュメ」には， 上記の内容に加え，「法情報の調べ方」，「法制定に 係る歴史的な背景」及び「薬事分野の裁判例や違反 事例」の 3 つの内容を掲載した。「法情報の調べ方」 には，「e-Gov 法令検索」5)を用いた法律や政省令等 の検索方法と,「厚生労働省法令等データベースサー ビス」而を用いた通知等の検索方法を記載した．併 せて，薬事に係わる実務を行うにあたっては，厚生 労働省，都道府県，職能団体等のウェブサイトから も有益な情報が得られることがある旨，説明を加え た。本教材は，本科目に係わる法令等の正確な検索 方法を示すことにより，授業終了後においても，必 要な法情報を取得できることを目的として作成し た。「法制定に係る歴史的な背景」は，授業範囲で 扱う法律や制度が設けられた（又は改正された）理 由を中心に, 当時の歴史的な背景を踏まえて記載し た。本教材は，本科目で扱う法律や制度の制定趣旨 の理解を促すために作成した。「薬事分野の裁判例 や違反事例」は，授業範囲で扱う法規定に違反した 事例に焦点を当て，参考文献》や判例データベー ス8)を用いて 2 点を抽出して記載した。掲載した裁 判例については, Supplementary Table 1 に示す. 本教材は，抽象的な法規定の内容を，実際に起きた 具体的な事実に当てはめて学習する機会を設けるた めに作成した.

「小テスト」は，講義前の前提知識を確認するた めの記述式の演習問題と, 講義後に学習した内容を 復習するための選択式の演習問題で構成した。これ らは，授業中に解答する時間を設け，その後に担当
教員が解説を行つた．本教材は，講義前の前提知識 を学生と教員が確認し，講義後に学習した知識を活 用しながら，学習目標を明確化させるために作成し た.

「Q\&A 集」は，授業後に学生から受けた質問と それに対する担当教員の回答を組み合わせた資料と した。「Q\&A 集」の配布を行った日は，講義の開 始時に質問と回答の内容を学生全員にフィードバッ クした。学生から受けた質問は 5 件であり，質問内 容については, Supplementary Table 2 に示す。本 教材は，本科目の授業を受けた後に，学生にとって 理解しにくい内容や，個別に気になっている内容な どを広く収集し，授業で不足していた情報のフィー ドバックや，次年度に向けた教材改善に役立てるた めに作成した。

なお，2018 年度に開講した本科目では，上記の 6 種類の教材を中心に授業を展開しており，特定の教 科書の指定は行っていない.

3. 調查対象 2018 年度の北里大学薬学部 4 年次必修科目「薬事関係法規」を受講した薬学科 （6 年制課程 254 名）及び生命創薬科学科（4 年制課 程 46 名）の 4 年生計 300 名を対象とした。

4. 調查内容と調查方法 本科目で使用した 6 種類の教材について，学習や理解を促すのに有効で あったかを，「1. まったく有効ではなかった」から 「5.とても有効だった」までの 5 件法で問うアン ケートとした。また，本科目に対する薬学生の意識 を広く抽出するために，「授業後の本科目に対する 印象 (自由記載)」について質問した。アンケート 用紙は，本授業の最終日に学生に配布し，本研究の 目的，アンケートへの参加は自由意思であること， 参加しない場合でも不利益は生じないこと，学会や 論文等で発表する場合には個人が特定されないよう 配慮することなどを説明した上で，研究への協力に 同意できる者のみが，講義室の出入口に設置された 回収箱に提出する方法により行った.

5. 分析方法 本科目で使用した 6 種類の教材 それぞれの評価（以下，「個別評価」という）を説 明変数，各回答者のすべての教材の評価平均值（以 下，「総合評価」という）を目的変数として customer satisfaction (CS) 分析9,10) を行った. CS 分析 は，アンケート調査等によって得られた個別評価と 総合評価の数値を基に，総合評価を高めるためにど 
Table 1. Results of the Individual Evaluation and Comprehensive Evaluation

\begin{tabular}{|c|c|c|c|c|c|c|c|}
\hline Teaching materials and individual evaluation & & 1 & 2 & 3 & 4 & 5 & Mean value \pm S.D. \\
\hline \multirow{2}{*}{ Lecture summaries } & $n$ & 1 & 5 & 36 & 103 & 99 & \multirow{2}{*}{$4.20 \pm 0.80$} \\
\hline & $\%$ & 0.4 & 2.0 & 14.8 & 42.2 & 40.6 & \\
\hline \multirow{2}{*}{ Search methods for legal information } & $n$ & 2 & 16 & 108 & 83 & 35 & \multirow{2}{*}{$3.55 \pm 0.85$} \\
\hline & $\%$ & 0.8 & 6.6 & 44.3 & 34.0 & 14.3 & \\
\hline \multirow{2}{*}{ Historical background to the enactment of laws } & $n$ & 3 & 8 & 84 & 102 & 47 & \multirow{2}{*}{$3.75 \pm 0.85$} \\
\hline & $\%$ & 1.2 & 3.3 & 34.4 & 41.8 & 19.3 & \\
\hline \multirow{2}{*}{ Case studies of judgments and violations in pharmaceutical laws } & $n$ & 1 & 2 & 51 & 121 & 69 & \multirow{2}{*}{$4.05 \pm 0.75$} \\
\hline & $\%$ & 0.4 & 0.8 & 20.9 & 49.6 & 28.3 & \\
\hline \multirow{2}{*}{ Class quizzes } & $n$ & 2 & 1 & 21 & 77 & 143 & \multirow{2}{*}{$4.47 \pm 0.74$} \\
\hline & $\%$ & 0.8 & 0.4 & 8.6 & 31.6 & 58.6 & \\
\hline \multirow{2}{*}{ Q\&A compilations } & $n$ & 1 & 12 & 59 & 105 & 67 & \multirow{2}{*}{$3.92 \pm 0.86$} \\
\hline & $\%$ & 0.4 & 4.9 & 24.2 & 43.0 & 27.5 & \\
\hline Comprehensive evaluation & & & & & & & $3.99 \pm 0.60$ \\
\hline
\end{tabular}

の個別評価の項目を優先的に改善すべきかを把握す る分析方法である。本研究の CS 分析は，相良 $ら^{9,10)}$ 及び管 ${ }^{11)}$ の方法を参考に行った. 各用語と分 析方法の概要は，以下の通りである．個別評価で 4 又は 5 が選択された比率（2 top 比率）を「満足度」 とした．満足度と総合評価との相関係数を「重要度」 とし, 満足度と重要度をそれぞれ偏差值に変換し て, 満足度の偏差值を縦軸, 重要度の偏差值を横軸 として「偏差值 CS グラフ」を作成した。偏差值 CS グラフは，原点 $(50,50)$ を中心にグラフエリ アを上下左右に 4 分割し，満足度が高く重要度も高 い右上エリアを「重点維持項目」, 満足度は高いが 重要度は低い左上エリアを「維持項目」，満足度が 低く重要度も低い左下エリアを「改善項目」, 満足 度は低いが重要度が高い右下エリアを「重点改善項 目」とした。CS 偏差值グラフの原点から各プロッ トまでの「距離」と，原点から各プロットを結んだ 線と基準線（原点と右下最下点を結んだ線）との間 の「角度」を算出し，求めた角度を「修正角度指数」 に変換した。最後に，距離と修正角度指数から各教 材の「改善度指数」を算出した．改善度指数は，一 般的に 5 未満を改善不要項目, 5 以上 10 未満を要 改善項目, 10 以上を即改善項目などとしており, ${ }^{11)}$ 薬学教育に関する先行研究でも同様の評価基準を採 用している. 12-16) すなわち, 改善度指数が大きい項 目ほど，ほかに比べ優先的に改善が必要な項目とい うことになり, 改善度指数が負の值を取る場合は,
改善度が低いことを意味している.これらの分析に は Microsoft Excel 2016 を使用した。 なお，個別評 価の一部が記入されていない回答者のデータは, CS 分析の対象から除外した.

授業後の本科目に対する印象については，形態素 解析により, 名詞, サ変名詞, 形容動詞, 固有名 詞，組織名，人名，地名，ナイ形容，副詞可能，未 知語，夕グ，感動詞，動詞，形容詞，副詞を抽出し た．その後，「分かる」と「わかる」は「分かる」 に統一するなど，同じ意味を持つ語句は 1 つの語句 に置き換えた。 上記の手順でコーディングした語句 の出現回数が 4 回以上となつた語句を用いて，クラ スター分析（Ward 法）を行い，同じ文章に出現し た語句を把握するためにデンドログラム（樹状図） を作成し，同時記載例と件数を確認した。これらの 分析には, KH-corder $3^{17,18)}$ を用いた。

6. 倫理的配慮 本研究は, 北里大学北里研究 所病院研究倫理委員会の承認を受けてから実施した （承認番号 18022）。集計した学生情報は，デー夕化 により個人が特定できないように配慮したうえで解 析を行った.

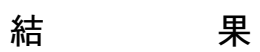

1. 教材評価の集計と CS 分析の結果 すべて の項目に記入した 244 名の回答を解析対象とした (有効回答率 $81.3 \%$ )。個別評価と総合評価の集計 結果を Table 1 に示す。次に CS 分析の結果を 
Table 2. Results of the Customer Satisfaction Analysis

\begin{tabular}{lcccccccc}
\hline \hline Teaching materials and their content & $\begin{array}{c}\text { Level of } \\
\text { satisfaction }\end{array}$ & $\begin{array}{c}\text { Level of } \\
\text { importance }\end{array}$ & $\begin{array}{c}\text { Deviation } \\
\text { value for } \\
\text { satisfaction }\end{array}$ & $\begin{array}{c}\text { Deviation } \\
\text { value for } \\
\text { importance }\end{array}$ & $\begin{array}{c}\text { Angle } \\
\text { Corrected } \\
\text { angle } \\
\text { index }\end{array}$ & $\begin{array}{c}\text { Distance } \\
\text { improvement }\end{array}$ \\
\hline Lecture summaries & 0.83 & 0.71 & 57.22 & 43.58 & 176.68 & -0.96 & 9.66 & -9.31 \\
\hline Search methods for legal information & 0.48 & 0.73 & 34.63 & 48.06 & 52.19 & 0.42 & 15.50 & 6.51 \\
\hline $\begin{array}{l}\text { Historical background to the enact- } \\
\text { ment of laws }\end{array}$ & 0.61 & 0.78 & 42.96 & 57.33 & 1.19 & 0.99 & 10.16 & 10.03 \\
\hline $\begin{array}{l}\text { Case studies of judgments and viola- } \\
\text { tions in pharmaceutical laws }\end{array}$ & 0.78 & 0.82 & 53.99 & 64.92 & 59.97 & 0.33 & 15.44 \\
\hline $\begin{array}{l}\text { Class quizzes } \\
\text { Q\&A compilations }\end{array}$ & 0.90 & 0.68 & 62.06 & 36.65 & 177.08 & -0.97 & 17.99 & -17.41 \\
\hline Overall average & 0.70 & 0.74 & 49.15 & 49.47 & 77.10 & 0.14 & 1.01 & 0.14 \\
\hline S.D. & 0.72 & 0.75 & & & & & &
\end{tabular}

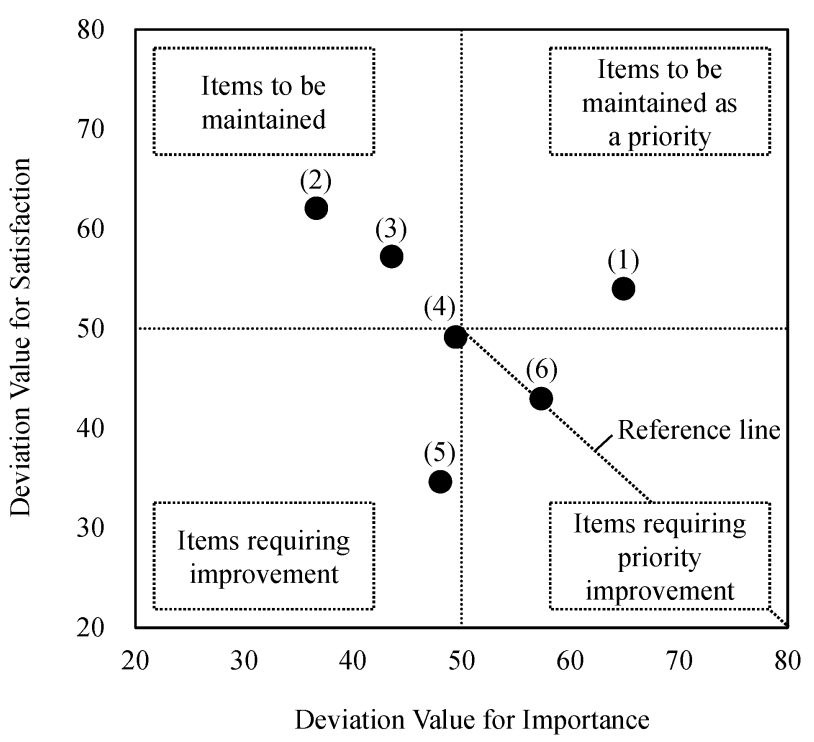

Fig. 1. Customer Satisfaction Deviation Value Graph

(1) Case studies of judgments and violations in pharmaceutical laws, (2) Class quizzes, (3) Lecture summaries, (4) Q\&A compilations, (5) Search methods for legal information, (6) Historical background to the enactment of laws.

Table 2 に示す．各教材の改善度指数は，「法制定 に係る歴史背景」10.03，「法情報の検索方法」6.51， 「薬事分野の裁判例や違反事例」5.15，「Q\&A 集」 0.14 ,「講義のレジュメ」 -9.31 , 「小テスト」 -17.41の順であった（Table 2)。偏差值 CS グラフ （Fig. 1）では，「薬事分野の裁判例や違反事例」は 「重点維持項目」に，「小テスト」と「講義のレジュ メ」は「維持項目」に，「Q\&A 集」と「法情報の 検索方法」は「改善項目」に，「法制定に係る歴史 背景」は「重点改善項目」にそれぞれ位置付けられ た.

\section{2. 自由記載の抽出語とクラスター分析の結果}

本科目に対する印象について自由記載のあった 216 名（有効回答率 $72.0 \%$ ）を解析対象とした。回 答者の平均文字数 \pm 標準偏差は, $9.43 \pm 7.66$ で あった． 形態素解析及びコーディング後の分析結果 を Table 3 に示す。これらの 28 種類の語句が文章 に含まれていなかった回答者は 25 名 $(11.57 \%)$ で あり，191名 $(88.43 \%)$ については，いずれかの 語句が文章に使用されていた。抽出された語句は, 「法律，日本語，文系，言葉，文字」などの科目の 特徵を示した語句，「覚える，暗記」などの学習観 に関する語句，「分かる，面白い，楽しい，丁寧， 良い」などの前向きな印象を示した語句，「難しい， 細かい，多い，複雑，かたい，大変」などの後ろ向 きな印象を示した語句などが抽出された。

次にクラスター分析の標準出力結果と併合水準を 参考に，クラスター数を 9 に調整したデンドログラ ム（樹状図）を Fig. 2 に示す。各クラスターは,

(1)「文字・大変・覚える・多い」, (2)「優しい・面 白い・先生」, (3)「暗記・科目・文系」, (4)「思う・ 授業・良い」，(5)「学ぶ・薬」，(6)「法律・細かい・ かたい・楽しい」, (7)「理解・丁寧・興味」, (8)「難 しい・日本語」, (9)「分かる・内容・複雑・言葉」 で構成された。それぞれの同時記載例と類似内容の 件数は以下の通りである.

(1)「覚えることが多い」(覚える一多い7 件),「文 字が多い」(文字一多い 4 件)，「覚えるのが大変」 (覚える一大変 4 件)，「文字がいっぱい，覚えきれな い」（文字-覚え 1 件）「量が多くて，法律って大変 
Table 3. Pharmacy Students' Impressions of the Course

\begin{tabular}{|c|c|c|c|c|c|c|c|}
\hline No. & Extracted words & $\begin{array}{c}\text { Frequency } \\
\text { (negative form) }\end{array}$ & $\%$ & No. & Extracted words & $\begin{array}{c}\text { Frequency } \\
\text { (negative form) }\end{array}$ & $\%$ \\
\hline 1 & Difficult & $47(0)$ & 21.76 & 15 & Hard & $7(0)$ & 3.24 \\
\hline 2 & Law & $45(0)$ & 20.83 & 16 & Fun & $7(0)$ & 3.24 \\
\hline 3 & Understand & $27(1)$ & 12.50 & 17 & Thorough & $7(0)$ & 3.24 \\
\hline 4 & Many & $20(0)$ & 9.26 & 18 & Learn & $6(0)$ & 2.78 \\
\hline 5 & Interesting & $16(0)$ & 7.41 & 19 & Humanities & $6(0)$ & 2.78 \\
\hline 6 & Remember & $15(0)$ & 6.94 & 20 & Good & $5(0)$ & 2.31 \\
\hline 7 & Teacher & $14(0)$ & 6.48 & 21 & Think & $5(0)$ & 2.31 \\
\hline 8 & Detailed & $13(0)$ & 6.02 & 22 & Word & $5(0)$ & 2.31 \\
\hline 9 & Course & $12(0)$ & 5.56 & 23 & Tough & $5(0)$ & 2.31 \\
\hline 10 & Class & $11(0)$ & 5.09 & 24 & Medicine & $5(0)$ & 2.31 \\
\hline 11 & Content & $11(0)$ & 5.09 & 25 & Memorize & $4(0)$ & 1.85 \\
\hline 12 & Complicated & $11(0)$ & 5.09 & 26 & Interest & $4(0)$ & 1.85 \\
\hline 13 & Kind & $8(0)$ & 3.70 & 27 & Characters & $4(0)$ & 1.85 \\
\hline 14 & Japanese & $8(0)$ & 3.70 & 28 & Understanding & $4(2)$ & 1.85 \\
\hline
\end{tabular}

だな」(多いー大変 1 件), (2)「先生が面白い」(先生一 面白い 7 件),「先生が優しい」(先生-優しい 4 件), 「優しい. 面白い」（優しい-面白い 3 件），(3)「社会 科系の文系科目」（文系一科目 3 件），「暗記科目」 (暗記一科目 2 件)，(4)「聞こうと思える授業」(思う一 授業 2 件)，「良い授業」(良い-授業 1 件)，(5)「薬 を販売する上で久かせない知識を学ぶ」（薬一学ぶ 3 件)，(6)「法律は規定が細かく難しい」（法律-細か い 4 件)，「法律な事が多いので，とてもかたい内容 で分かりにくいところがあった（原文のまま）」（法 律一かたい 1 件),「かたい. 細かい」（かたい一細か い 1 件)，「かたい。眠い。けれど楽しい」（かたいー 楽しい 1 件)，(7)同時記載はなくすべて単独の語句 のみ，8「日本語が難しい」(日本語-難しい 6 件), (9)「とつつきにくそうな内容かと思っていたが，例 え話などで分かりやすく教えてもらえた」（分かる内容 1 件)，「漢字が多く似ている言葉が多いため覚 えるのが大変. 内容が複雑」(言葉-内容-複雑 1 件).

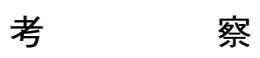

偏差值 CS グラフ（Fig. 1）から，「薬事分野の裁 判例や違反事例」は「重点維持項目」に該当し，本 科目の学習に有用で興味や関心が高い教材であった 可能性が示唆された。本教材は，法規範を具体的な 事実に当てはめて学習することができるので，本科 目の学習に効果的であったと評価された可能性があ る.「重点維持項目」に分類されたにもかかわらず,
計算上，改善度指数が比較的高く算出された（Table 2) のは，重要度が非常に高かったためだと考 えられる. ${ }^{19)}$ 今後さらに近年の報告20)などを参考に 定期的に内容の充実を図ることで，より一層教材と しての価值が高められる可能性がある.

「小テスト」と「講義のレジュメ」は，いずれも 偏差值 CS グラフの維持項目に該当した。「小テス 卜」は，満足度が最も高く，改善度指数が最も低 かったが，これには，本教材が本科目の成績評価の 一部であったことが関係している可能性がある. 「講義のレジュメ」は，「小テスト」についで，満足 度が高く, 改善度指数が低かったが，本研究対象の 年度では, 特定の教科書の指定を行っていなかった ため，本教材の存在が有用であったと評価された可 能性がある. 両教材ともに，今後も継続採用しなが ら, 次年度以降は小テストに出題した演習問題や, 講義のレジュメに記載された解説文に関する改善点 を具体的に把握する必要がある。

$「 \mathrm{Q} \& \mathrm{~A}$ 集」は，「改善項目」の原点付近に位置し ており，改善度指数は低く，教材としては平均的な 評価であった。ただし，今回収集された質問の件数 は全部で 5 件と少なかったため, 本教材の反省点と して，ミニッツペーパーなどのコミュケーション ツールを用いた方が，より多くの疑問点などを収集 できた可能性がある。また，収集された質問は，本 授業の内容で分からなかったことの確認と，授業科 目に係わる相談の 2 種類に大別される内容であった 
(1)

(2)

(3)

(4)

(5)

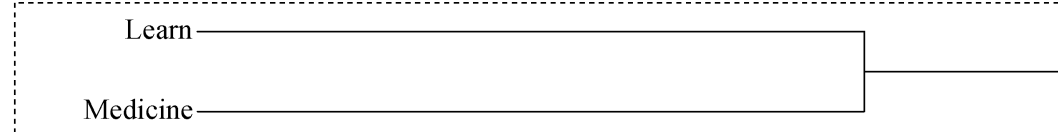

(1)

Remember

$$
\text { Many }
$$

Memorize

$$
\text { Course }
$$

Humanities

$$
\text { -...-...-...-. }
$$

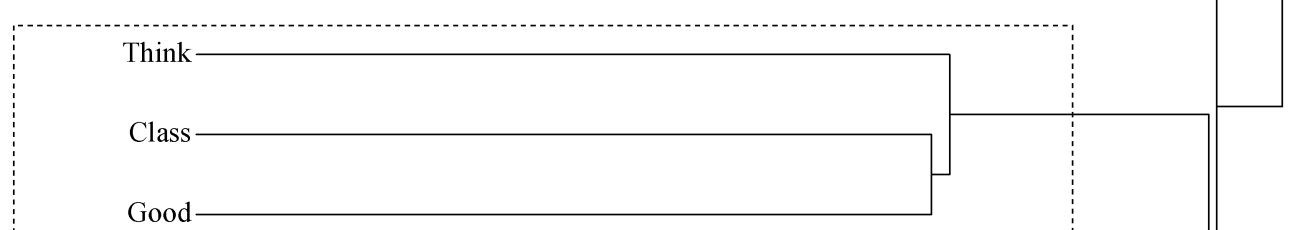

(7)

$$
\text { Characters }
$$

$$
\text { Tough }
$$

(6)
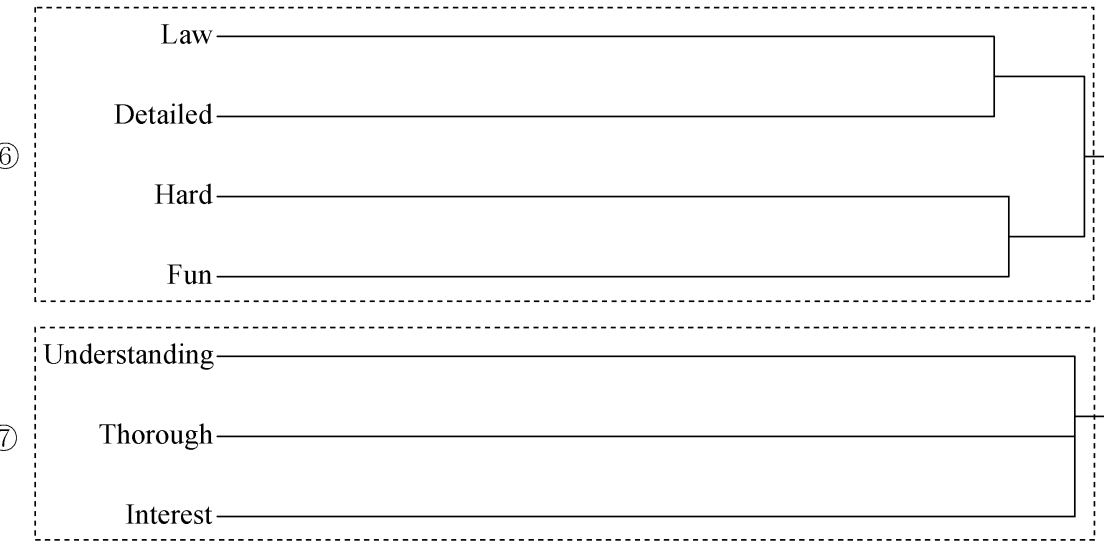

(8)
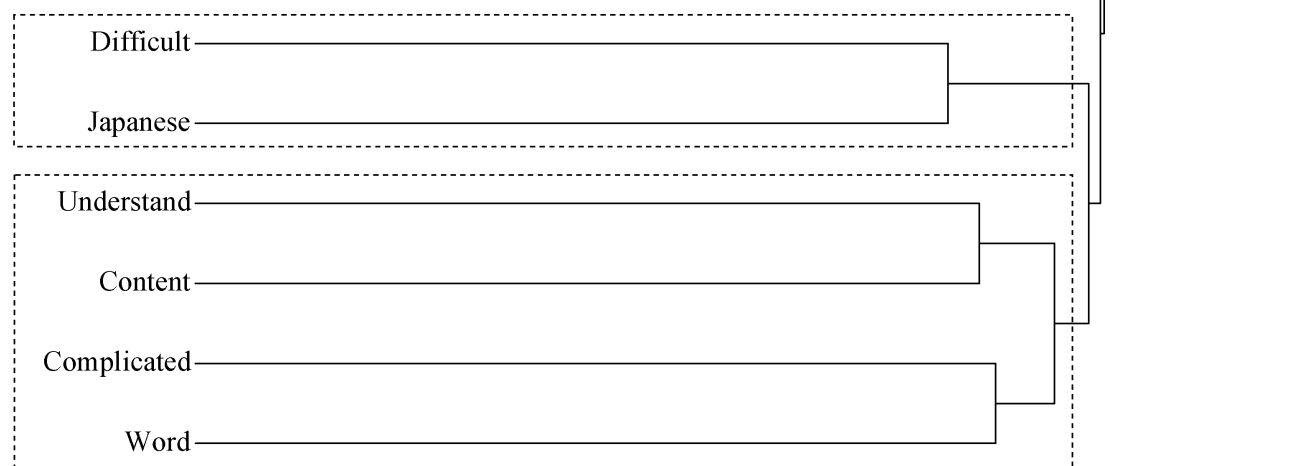

Fig. 2. Results of the Cluster Analysis 
(Supplementary Table 2). 前者は, 教材改善のた めの形成的評価や当該年度のフィードバックに役立 てられると考えられるが，後者については，多様な 考え方や視点を知る機会にはなるが，学生全員に対 して一律にフィードバックするのではなく, 学習支 援システムなどを利用して個別に参照できるような 環境の整備を検討する必要がある.

「法情報の検索方法」は, 「改善項目」に該当し， 満足度が最も低く, 改善度指数が 5 を超えていた。 本教材の反省点として, 本年度の授業では, 初回の 授業時に当該内容を紹介するのみで，実際に「小テ スト」などの演習教材で活用する機会は特に設けて いなかった。 今後は, 実際の薬学関係者の業務に準 拠した演習課題を作成し，本教材内容の活用の機会 を設ける方法に変更する必要がある.

「法制定に係る歴史背景」は，「重点改善項目」に 該当し, 改善度指数が 10 を超え, 最も改善が必要 な教材と評価された。重要度が高いため興味や関心 が高い教材であったが，本科目の学習に有用ではな かったと評価されたことになる。本教材の反省点と して, 教材の記載内容が不十分であったことや，学 習における本教材の位置づけや目的が不明確であっ たことが考えられる，今後は，本教材の記載内容を 充実させるとともに, 法律や制度の制定趣旨と本教 材の内容を関連させながら授業を実施する必要があ る.

本科目に対する印象では，「難しい」が最も回答 が多く (Table 3), 特に「日本語」が「難しい」と いう同時記載が多く確認された（Fig. 2)。確かに, 法律などには，学生が日常的には使用しない用語が 含まれており，「及び」と「並びに」や，「又は」と 「若しくは」などを始めとする法令用語の基本的な ルールについて, 学生がそれらを確実に理解しなが ら学習を進められる教材設計にはなっていなかっ た。また「何人も（なんぴとも）」や「蓋然性（が いぜんせい)」などの用語について，読み仮名や用 語の説明を教材には記載しておらず，教材内容の記 載方法に配慮が足りなかった可能性がある。このよ うなことから，「講義のレジュメ」などの作成にあ たつては, 学習の基礎となる事項から段階的に順序 よく学習が進められるよう記載内容を検討する必要 がある. 他の抽出語と同時記載例からも, 薬学生の 正直な印象が抽出されたが，単に法律などの文章を
暗記する科目という認識については，学習した内容 を想起できるだけではなく, 別の文脈や場面でも知 識が活用できることが最終的な目標であることを, 授業用教材の中でも改めて明確に提示しておく必要 がある。

なお, 本研究の限界として, 北里大学薬学部 4 年 生前期の科目で取り扱つた授業内容における教材の 評価であることが挙げられる，つまりは，薬学教育 モデル・コアカリキュラムや 4 年制薬学教育課程編 成上の参照基準で示された薬事法規分野のすべての 内容を網羅した教材の評価とはなっていない。しか し, 薬事分野の法律や制度の教育方法は, 他の範囲 でも類似していることが多いため, 本研究の結果 は，当該分野の他の法律や制度に関する教材設計に おいても参考になると考える.

\section{結論}

本研究により，薬事法規分野の授業用教材のう ち, 薬事分野の裁判例や違反事例は, 当該分野の学 習に有用で興味や関心が高い教材であることが示唆 された. 講義のレジュメや小テストについても有用 性が高く, 今後も継続して使用することが望ましい ことが確認された。一方，法制定に係る歴史背景や 法情報の検索方法については, 教材設計の改善が求 められ，Q\&A 集については，学生からの質問の収 集方法やフィードバックの方法を見直す必要があっ た。学生からは当該分野の科目で使用される用語の 難しさなどが指摘されており，学習の基礎となる事 項から段階的に順序よく学習が進められる教材設計 を意識する必要がある，また，本科目を単なる暗記 科目だと認識している学生も一定数存在しているた め, 学習した内容を活用できることが学習目標であ ることを授業用教材にも明確に示すべきと考える.

謝辞本研究の実施にあたり, 有益なご助言を 賜りました北里大学薬学部 清野正子教授, 東京大 学工学部 黒田大祐講師に深く感謝申し上げます.

\section{利益相反＼cjkstart開示すべき利益相反はない.}

\section{Supplementary materials この論文のオンライ} ンに Supplementary materials（電子付録）を含ん でいる. 


\section{REFERENCES}

1) The Pharmaceutical Society of Japan. "Model Core Curriculum for Pharmaceutical Education -2015 version-," March 2018: 〈https:// www.pharm.or.jp / kyoiku / pdf / corecurri eng180426.pdf $\rangle$, cited 24 December, 2019.

2) Science Council of Japan. “Daigaku Kyouiku no Bunyabetsu Shitsuhoshou no tameno Kyouiku Katei Henseijou no Sanshou Kijun, Yakugaku Bunya (4 nensei kyouiku o chuushintoshite)," August 17, 2017: 〈http:// www.scj.go.jp / ja / info / kohyo / pdf / kohyo23-h170817.pdf $\rangle$, cited 24 December, 2019.

3) The Pharmaceutical Society of Japan. "Iryoujin Yousei toshiteno Yakugaku Kyouiku ni kakaru Kyouzai ya Kyouiku Houhou no Kaihatsu ni kansuru Chousa Kenkyu," May 2013: 〈https://www.pharm.or.jp/kyoiku/pdf/med personseduWS_001report.pdf $\rangle$, cited 24 December, 2019.

4) The Pharmaceutical Society of Japan. “Regulatory Science ni kakaru Kyouzai ya Kyouiku Houhou no Kaihatsu ni kansuru Chousa Kenkyu," March 2015: 〈https:// www.pharm.or.jp/kyoiku/pdf/regsci150708. pdf $\rangle$, cited 24 December, 2019.

5) Ministry of Internal Affairs and Communications. "e-Gov Hourei Kensaku.": 〈https:// elaws.e-gov.go.jp/search/elawsSearch/elaws_ search/lsg0100/>, cited 24 December, 2019.

6) Ministry of Health, Labour and Welfare. "Kouseiroudoushou Houreitou Database Service.": 〈https://www.mhlw.go.jp/hourei//, cited 24 December, 2019.

7) Akimoto Y., "Iryoukagojiken kara Manabu Yakuzaishi no Shippaigaku," Nanzando Co., Ltd., Tokyo, 2013, pp. 1-92.

8) Dai-ichi Houki Co., Ltd. "Dai-ichi Houki Houjouhou Sougou Databese.”: 〈https:// www.d1-law.com/>, cited 24 December, 2019.

9) Sagara H., Kitamura Y., Furuno K., Shibata K., Gomita Y., Jpn. J. Pharm. Health Care Sci., 32, 295-305 (2006) .

10) Sagara H., Kitamura Y., Nawa H., Okazaki H., Sendo T., Gomita Y., Jpn. J. Pharm. Health Care Sci., 33, 331-338 (2007).

11) Kan T., "Jitsurei de Yokuwakaru Anketochosa to Toukeikaiseki," Natsumesha Co., Ltd., Tokyo, 2011, pp. 196-209.

12) Tsuji Y., Hiraki Y., Kamiyama T., Mizoguchi A., Sadoh S., Kawakami C., Tamura Y., Narisue M., Matsutani H., Kamimura H., Sasaki H., Jpn. J. Pharm. Health Care Sci., 34, 486-495 (2008).

13) Tsuji Y., Hiraki Y., Mizoguchi A., Sonemoto E., Hirata T., Yokoyama Y., Hirao K., Kamimura H., Karube Y., Jpn. J. Pharm. Health Care Sci., 35, 525-533 (2009).

14) Maenaka A., Ohtsu F., Goto N., Ogawa M., Ohta T., Kurosawa N., Mochizuki M., Yamada Y., Jpn. J. Drug Inform., 16, 157-168 (2015).

15) Kutsukake M., Tsuji Y., To H., Jpn. J. Pharm. Health Care Sci., 42, 107-112 (2016).

16) Akiyama S., Yamawaki T., Irie S., Takatori S., Kayou H., Iha T., Namba H., Takada K., Kobayashi N., Matsuoka I., Sakai I., Japanese Journal of Pharmaceutical Education, 1, 59-66 (2017).

17) Higuchi K., Ritsumeikan Soc. Sci. Rev., 52, 77-91 (2016).

18) Higuchi K., Ritsumeikan Soc. Sci. Rev., 53, 137-147 (2017).

19) Teramachi H., Nakamura M., Takashima E., Kubota M., Adachi T., Tsuchiya T., Jpn. J. Pharm. Health Care Sci., 34, 374-380 (2008).

20) Eguchi R., Kato M., Kaneko E., Kusaba K., Yoshikawa M., Yamano T., Seo T., Hagihara A., Yakugaku Zasshi, 135, 501-506 (2015) . 